\title{
Negotiating languages of suffering in northern Uganda
}

\author{
Lars Hedegaard Williams ${ }^{1}$ \\ ${ }^{1}$ London School of Economics and Political Science, Firoz Lalji Centre for Africa, Houghton Street WC2A \\ London UK
}

\begin{abstract}
D rawing on ethnographic fieldwork in northern Uganda, I argue that psychiatric notions of suffering brought into the region by humanitarian intervention programs interact with local concepts of suffering (based in spirit-idioms) in two ways: In some cases, the diagnostic notion of PTSD and its vernacular counterpart "trauma" psychologize the local cosmology, transforming local spirit concepts from social or moral categories, to psychological ones. In other cases, psychiatric discourses hinged around "trauma" become spiritualized or enchanted, where the concept of trauma becomes usurped by and part of local cosmology. In an attempt to understand these processes, I suggest understanding concepts of suffering through their use in social practice and based on pragmatist epistemology. If viewed as a pragmatist concepts, I argue, it becomes possible to understand the social life of concepts of suffering (such as "trauma") when they become globalized and negotiated in new contexts and social practices.
\end{abstract}

Keywords: Trauma, Pragmatism, Suffering, Psychologization, Enchantment, Psychiatry.

\section{Introduction}

Psychological trauma therapy is being deployed around the world by NGOs and through humanitarian intervention programs on a very large scale. It has been discussed at length in the anthropological literature whether notions of suffering from the Global North articulated in psychological and psychotherapeutic terms can be successfully implemented in cultural contexts with different notions of suffering and healing (Hinton \& Good, 2016; Broch-Due \& Bertelsen, 2016; Hinton \& Hinton, 2015; Hinton \& Lewis-Fernández, 2011). Critics have argued that the diagnostic language from the Global North has developed out of specific cultural and historical circumstances and therefore is not necessarily suitable for cross-cultural understanding and treatment (Summerfield, 1997; Bracken, 1998; 2002; Torre 2019) and that it constitutes forms of therapeutic governance over the developing world by the Global North (Enomoto, 2011; Pupavac, 2004; 2006). These critiques have highlighted the inherent ethnocentrism in much of the diagnostic vocabulary and thinking and have contributed to an ongoing critical debate on cross-cultural psychiatric practices. Nevertheless, many of these 
critiques of the globalization of the trauma discourse, fruitful as many of them have been, build on assumptions of an unbridgeable gap between 'western culture' equated with modernity and nonwestern cultures viewed as traditional (Bubandt, 2008).

An alternative way to understand culture, tradition and modernity, which is widespread in the social sciences today, is that of a global space of flows, where we all partake in a globalized and ever-changing cultural landscape from different perspectives or entry points (Tsing, 2012; Eriksen, 2010; 2014; Bubandt et al., 2007). Holding this more processual framework of culture and globalization as a backdrop, the relevant questions regarding the application of psychological and psychiatric concepts in describing suffering, become less of the kind questioning as 'is this concept (e.g. "trauma") compatible with local culture?' and more along these lines of 'what kind of life does the concept (e.g. "trauma”) take on within local culture?'

A handful of studies have examined the spread of trauma discourses in this way. Nils Bubandt (2008; 2012; 2015) has examined how the globalized discourse of trauma in Indonesia became intertwined with local idioms of witchcraft along with the image of the vampire Dracula into new forms of 'traumatized spirits'. Erica Caple James $(2004 ; 2010$; 2012) has examined how discourses of trauma in Haiti become the hinges around which 'occult economies' pivot and thus create new forms of political subjectivity. Sharon Abramowitz $(2009 ; 2010)$ has shown how specific culture-bound disorders becomes transformed into local idioms of trauma, thus collapsing a local cosmological entity into a "pidgin psychiatry" (2010, 376) that fits within humanitarian epistemologies. Other current studies of trauma discourse and psychotherapeutic interventions are also beginning to move towards examining the pragmatics and social lives of trauma discourses (Behrouzan, 2018; Broch-Due \& Bertelsen, 2016; Argenti, 2016). This article walks along the same path as these studies particularly following Bubandt, (2012, 2008), Abramowitz (2009; 2010) and Brinkmann and colleagues (Brinkmann, 2016; 2014; Kirkegaard \& Brinkmann, 2015) ${ }^{1}$ in examining what kind of social life discourses of trauma take on in the vernacular, and contributes by exploring two different processes by which the diagnostic language of suffering - and in this case with a particular focus on post-traumatic stress disorder (PTSD) and its more vernacular counterpart "trauma" - enters local worlds in northern Uganda after the end of the recent armed conflict.

I argue that the introduction of a diagnostic language to describe suffering related to war and violence, despite being ubiquitous and dominating, does not replace nor exclude local

\footnotetext{
${ }^{1}$ In reference here to Brinkmann and colleagues I follow in this path analytically, not regarding the empirical object of study. With Bubandt $(2012,2008)$, Abramowitz $(2010,2009)$ and the other anthropologists, I mean in regard to both empirical object and methods of analysis.
} 
cosmological understandings of violence-related suffering, but merges with these in different ways. At least two observable processes take place in this encounter. First, in some cases the introduction of trauma discourses psychologize local cosmology, so spirit concepts, which would usually refer to social or moral categories, have come to refer to psychological ones, and traditional cleansing rituals become viewed as a kind of psychotherapy. Secondly, in other cases, discourses of trauma themselves become spiritualized or enchanted, where the concept of trauma has been usurped by, and become part of, local cosmology. These processes can be viewed as a continuous negotiation of, what cultural psychologist Svend Brinkmann (2014) calls, languages of suffering. I arrive at these conclusions by way of an analysis building from a pragmatist approach to psychiatric concepts and discourse focusing on what people do with specific concepts (such as "trauma") (Kirkegaard \& Brinkmann, 2015; Brinkmann, 2012; Abramowitz, 2010; Bubandt, 2008) Finally, I point towards some epistemological issues connected to the debates on cross-cultural studies of trauma, and suggest a concept of trauma, which builds on pragmatist epistemology, along the lines suggested by Brinkmann (2014). Through this examination and discussion, I seek to contribute to debates on what happens to discourses of suffering when they are exported from one cultural context to another though the practices of humanitarian intervention programs.

\section{Methodology}

The empirical material is based on eleven months of fieldwork conducted between 2016 and 2019. During my first longer trip in 2016, I conducted interviews with psychologists, local counselors and employees of four different NGOs working with mental health and psychosocial programs in northern Uganda. The work of the respective NGOs differs somewhat in practice, but all of them are dealing with psychosocial and mental health issues connected with the consequences of the war, and all have Western diagnostic discourses of trauma as central to their work. Eventually, my focus narrowed to two particular NGOs working specifically with psychotherapy for post-traumatic stress disorder (PTSD). I chose these particular NGOs for both reasons of their particular approach to psychotherapeutic intervention and because of access: My main interest was to study an NGO that worked specifically with psychotherapeutic intervention for PTSD, more than others who worked more broadly with "psycho-social support" programs. I also had better access to these particular NGOs, because I had made an initial agreement with the leading clinician from one of them that I would be allowed to follow their program over several months, do observations and interview the staff. The other NGO, I gained access to through my field assistant, a young Ugandan woman whom 
I had been working with for several years and who used to work for the second NGO. The staff of the first NGO were partially Europeans who were there for short time periods of time as part of their training in clinical psychology and research, and partially Acholi counselors who conducted the therapeutic sessions. Along the way, I became acquainted with the European junior staff, with whom I continually met with outside their office spaces and talked to about their work. I followed their work closely for a duration of several months. I interviewed the Ugandan counselors about their training at the NGO and the way they conducted their psychotherapeutic counseling; afterwards I conducted several follow-up interviews with them over the next few months. During this period, I focused mainly on one group of counselors, four women and one man, with whom I spent most of my time. I conducted three formal interview rounds with each of the counselors, and additionally, two rounds of group interviews with all of them present, besides many informal conversations with them and participant observations at the NGO headquarters. All interviews were conducted in English, since everyone was fluent in it. We did, however, often discuss translations of English terms into the local Acholi language and back, and we often reflected together on epistemological issues arising around these translations. These conversations could be viewed as a process of validity for my understanding of the use and meaning of local concepts. I was also allowed by the senior psychologist at the first NGO to sit in on a series of supervision meetings, where the counselors would present their therapeutic cases to the senior psychologist and receive supervision and guidance on how to understand and deal with the specificities of the cases. The second NGO I focused on, was mainly in the latter fieldtrips, where I had established contact through my field assistant and through 'snowballing' the co-worker of my first contacts. During my work with the second NGO my field assistant would help me significantly in many and lengthy discussions about her own training with the NGO and how she and her co-workers had learned to think with and use psychiatric concepts, mainly "trauma". This became a second process of validating my understanding of the meaning and use of local concepts. On later fieldtrips in 2017, 2018 and 2019 I would return to some of the NGO employees from both NGOs for more informal conversation about their work. I still stay in contact with few of them over social media. As I had different agreements with the various organizations about procedures to preserve anonymity, I have decided to keep them all equally anonymous. I have generated the material for the present article over several years and many fieldtrips, however, there are clear limitations to this study. The most serious of these is that it was not possible for me during my fieldwork to interview the counselors' clients and how they would utilize concepts of "trauma". Therefore, I could only gain access to the clients' perspectives through conversation with the 
counselors and other staff at the NGO. This weakens the discussion somewhat, since the client's perspectives on psychotherapeutic practices aimed at them are of key importance to the empirical and analytical context. However, it does not weaken the overall argument, since the argument is not centered around the efficiency of the trauma intervention, but on the social life of the concepts and practices that are at the core of these interventions.

I also interviewed local community members about the practices of the NGOs psychotherapeutic interventions, along with specific local community members who have been particularly engaged with the NGOs in various ways, for example as counselors, or with religious clergy who have collaborated with NGOs on various kinds of psychotherapeutic interventions or projects. For prolonged periods between 2015 and 2018, I lived with a family in a rural area where several family members had in the past worked for another NGO. During this period, I did 18 additional interviews on the topic of psychotherapeutic counseling and causes of mental disorder as related to spirits and/or trauma. Ethical approval for my research was obtained through Gulu University and through the Uganda National Counsel for Science and Technology, where I did a protocol presentation in front of the board of representatives before, in 2016, receiving my official ethical clearance for my research.

\section{The LRA war, haunting spirits and psychotherapeutic intervention in northern Uganda}

The Acholi people of Northern Uganda have seen several decades of war and extreme violence. During the conflict in the 1990's nearly the entire population was displaced to camps for internally displaced persons (IDP camps) by the government 'to protect them' from the rebel group Lord's Resistance Army (LRA), which fought the government from the mid-1980s to 2006. Besides killings, mutilations and abductions by the rebel group, the population also suffered atrocities at the hands of the government to an extent where scholars have described life in the camps as 'social torture' (Dolan, 2008). The rebels abducted tens of thousands of children and youth to serve as fighters and 'wives' to the commanders (Allen \& Vlassenroot, 2010; Dolan, 2008). The atrocities committed over several decades have been devastating, and though the guns fell silent more than ten years ago the region is still dealing with high rates of poverty, alcoholism and suicide (Kizza, et al. 2012). Psychological therapy, locally known as 'counseling,' was brought into the region by foreign NGOs in the 1990s 
with the HIV/AIDS programs, where it emerged in relation to HIV/AIDS diagnostics ${ }^{2}$. During the late 1990s, the Acholi region saw the dawn of reception centers to take care of the returnees from the bush (Verma, 2012; Allen \& Schomerus, 2006). Here, psychological therapy became a standard process and several of the reception centers worked together with NGOs who could extend the offer of psychotherapy beyond the time that the returnees would spend at the reception centers.

Since then, many NGOs have come along to treat and to measure the repercussions of war with the instruments of western psychology. As Lawrence Kirmayer writes in the introduction to a current volume on cross-cultural studies of PTSD (Hinton \& Good, 2016). "Stress and trauma have become globalized languages of suffering and healing, and the construct of PTSD is at the center of this discourse,". This surely goes for northern Uganda as well. One study from 2006 found the highest concentration of depression and PTSD measured in a post-conflict area in northern Uganda (Roberts et al., 2008). Within the population tested, these studies found depression scores of $67 \%$ and PTSD scores of 54\% measured with the Hopkins Symptom Checklist-25 and the Harvard Trauma Questionnaire. Another study from 2012 found that there were still 25 different NGOs working in the Acholi region dealing specifically with trauma therapy six years after the end of the war (Meinert \& Whyte, 2020). Thus, northern Uganda seems at first glance to have become part and parcel of an ever expanding 'empire of trauma' (Fassin \& Rechtman, 2009)3. However, the people of Acholiland, like everywhere else, have their own conceptions of war-related disorders, which predate the introduction of the psychiatric and diagnostic discourses. In traditional Acholi cosmology, the idea of spiritual pollution or possession connected to 'bad' or immoral death is known as cen. Cen is acquired by e.g. killing another person or by being in areas where people have been killed or where dead bodies have been treated in an incorrect manner (Victor \& Porter, 2017; Finnström, 2003). Symptoms of cen can cover experiences of nightmares, changes of personality, loss of memory, heightened aggression, uncontrolled emotions and visions of the dead. Thus, foreign researchers and NGO-workers often understand the symptoms of cen as the expression of traumatic experiences connected to the years of war and violence (Victor \& Porter, 2016). However, within recent years, the interpretation of these symptoms have by many locals also become connected to the diagnostic languages of suffering from the Global North.

\footnotetext{
${ }^{2}$ There where of course traditional ways of counseling in Acholi predating the introduction of western psychological therapy (Harlacher, 2009; p’Bitek, 1971).

${ }^{3}$ For an elaborated critique of the notion of "empire of trauma" specifically related to northern Uganda, see Meinert \& Whyte, 2020 and Williams \& Meinert, 2021.
} 


\section{Psychologizing the spirit world}

As mentioned above, humanitarian aid and development agents poured into the Acholi-region during the 1990s en masse. In the process of arranging trauma relief programs, local concepts in Acholi where scrutinized for the equivalence of the English 'trauma' and its diagnostic specification PostTraumatic Stress disorder (PTSD). There is no word in Acholi that directly corresponds to the English (diagnostic or lay use of) 'trauma', but local concepts like ajiji (intense fear or stress), tam ma dwong (over-thinking) or wiye obale (loss of senses or 'broken mind') were tried out for size (Meinert \& Whyte, 2020; Victor \& Porter, 2016; Harlacher, 2009). In this process, the concept of cen - the idea of vengeful spirits of the dead returning to claim justice - became an often used translation for trauma, because signs or symptoms of cen would roughly correspond to those of $\mathrm{PTSD}^{4}$, and for many foreigners cen became equivalent to a local idiom of trauma ${ }^{5}$. The logic applied by the NGOs working with psychotherapy is that trauma or PTSD is the actual underlying entity, and 'cen' (or whichever local concept is used) is simply a local word for that real, underlying entity. A consequence of this is a psychologization of the local concepts used, and thus a psychologizing of the spirit world in this context. The concept of psychologization refers to something becoming psychological, understood in light of psychological concepts and theories or confined to the realm of the intra-personal, emotional, and thus (often) a de-politicized and de-moralized sphere. (De Vos, 2012; Madsen \& Brinkmann, 2010). Psychologization has been widely described in the realm of the western hemisphere over the course of the 20th century (De Vos, 2013; Kofod, 2017) ${ }^{6}$, but has first recently been applied to analysis of humanitarian intervention in non-western countries (De Vos, 2011; Fassin, 2008; Pupavac, 2004; 2016). As a core example of how local Acholi concepts and rituals have been psychologized is the case of cen, the vengeful spirits of the dead, as it is understood by employees of one of the NGOs I followed, who engage in a broad spectrum of work considered as mental health intervention. Part of the service the NGO provides as psychosocial support is the arranging and financing of cleansing rituals to help the community with problems connected to cen. The process works as such, that when community members experience a problem with cen, e.g. when certain areas where massacres have taken place become haunted or cause people to become ill, they will turn to

\footnotetext{
${ }^{4}$ The question of whether symptoms of cen and PTSD are equivalent to each other is complicated for a series of reasons, the most present being one of classification: Where PTSD is presented in the DSM diagnostic manual as a monothetic category, where certain criteria must be met before a phenomenon qualifies for the category; Cen, on the other hand, can be said to be a polythetic class, characterized by family resemblance.

${ }^{5}$ See e.g. Neuner et al., 2012; van Duijn et al. 2010; Harlacher, 2009.

${ }^{6}$ These debates originated from narrow academic circles around German philosophers Frege and Husserl, and their critiques of the psychologization of logic and epistemology in the writings of e.g. John Stuart Mill (De Vos, 2011).
} 
their local and cultural leaders for help. The community members will ask for a cleansing to be done of the area, hereafter the cultural leaders will turn to the NGO for help with arranging and financing the event ${ }^{7}$. The NGOs would then sponsor the expenses of the cleansing ritual, which are often very expensive in e.g. animals for sacrifice, salary for the ritual leaders, etc. and would during the same event offer psychological counseling. When interviewed on the issues, several people from the NGO, as well as a local psychiatrist working with the NGO, expressed their understanding of the cleansing ritual as a local form of psychological therapy. Another local employee, who has worked many years for one of the NGOs doing the cleansing rituals, explains that the idea of cen has changed over time along with the psychotherapeutic interventions:

Traditionally people feared certain areas that were connected to the spirits, like the streams, certain forests, large mountains, under very big trees. These places where traditionally seen as places the bad spirits would go to, when they are chased away from people who suffer from their presence. Today many people will see this as old fashioned. Today, when we deal with the places where atrocities have taken place, like the massacre in Lukodi for example, where people are bothered by ... hmm, demonic kinds of things that appear here, then people don't talk about it in the same way. Today we know that science can explain this, and that it is connected to trauma from the war. That it creates trauma inside you, when you experience atrocities (NGO employee, northern Uganda, 2017).

This kind of explanation, expressing an urge to understand the world in "modern" and scientific, an essentially psychologized terms, is widespread today, particularly in more urban centers and among younger people. This understanding of how the spirit world of cen has changed during times of mental health interventions is a process where spirits as social or moral categories have to a certain degree become psychologized through diagnostic discourse. It is important to underscore, that it is not all of Acholi cosmology, which has been recast in psychological categories, and it is perhaps mainly an expression among certain groups. However, a psychologized way of using concepts like cen, as referring to emotional disturbances and suffering connected to experiences of violence - rather than

\footnotetext{
${ }^{7}$ NGOs sponsoring rituals in northern Uganda is more commonly known from the reconciliation ritual mato oput, where the clan of a killer and the clan of the victim are brought together for reconciliation (Allen, 2008).
} 
to social dynamics or moral trespass - has nevertheless become common, not only by the foreign NGO-workers who deal with cleansing rituals as trauma therapy, but also by the local staff and the people who are the beneficiaries of these services. As historian of science, Roger Smith $(1997,577)$, wrote in his volume on the human sciences, the twentieth century was a time when "everyone learned to be a psychologist [...] able and willing to describe life in psychological terms". Smith was here mainly referring to the northern hemisphere, but it seems that this trend has spread much broader today.

\section{The vernacularization of trauma}

The logic of psychosocial interventions concerning trauma, however, did not arrive and live on in Acholiland as a purely global imaginary, psychologizing the local cosmology as its only effect. Rather, psychosocial technologies and practices have also - simultaneously with the psychologization of cosmological notions - become vernacularized by the local staff employed by NGOs and by psychologists and health workers who tried to make the psychosocial logic more intelligible to the local population, along with reference to and 'piggybacking' on, earlier health interventions such as HIV/AIDS counseling.

One of my key informants explained how his first encounter with the concept of trauma, was when he would work for an NGO who would deal with HIV/AIDS patients. Here he learned that getting an HIV-diagnosis "could cause trauma in people" and this could render the patients "in need of trauma counseling”. During the 1990's, trauma counseling became connected to other events, as the NGOs bringing psychological trauma therapy settled in the IDP camps that were spread around northern Uganda as a consequence of the armed conflict. Here it became known, that "trauma is what happened to you in the bush" or "when you have experienced atrocities" as people would often say. In the reception centers, returnees from the rebel groups would often receive psychological counseling and learn that many of them were "traumatized child soldiers" (Verma, 2012; Allen \& Schomerus, 2006), a category intimately connected to globalized ideas of a diagnostic discourse in humanitarian intervention programs. Many NGOs who dealt with trauma counseling, worked with the reception centers and would do psychotherapy with the returnees afterwards in a variety of ways, and would also deal with local understandings of repercussions of war - as e.g. cen or spiritual curse (kiir) - in very different ways. Some NGOs would, as in the case above, actively engage with the spirit world by supporting and financing cleansing rituals, while others would actively dissuade their clients from beliefs in witchcraft e.g. through practices of psychoeducation (Williams, 2020). 
Interestingly enough some of the cases where the NGOs put more emphasis on dissuading people from traditional beliefs, were also cases where ideas of trauma and practices of psychological counseling would merge with practice and ideas of spirits and demons. Another NGO, which I followed for a longer duration of time, would take DNA samples at the beginning of every therapy session by either hair or saliva samples. This was done to search for correlations between DNA material and the development of PTSD. It nevertheless had the side effect of clients thinking their counselors where witches or demonic creatures $\left(\right.$ lute $\left.p i i^{8}\right)$, who would take these bio-samples for purposes of witchcraft. As one of the psychological counselors told me:

We keep explaining that we are not the lute pii [evil spirits]. Many understand, but there are still ones who keep thinking 'arh, these foreigners, they are the lute pii [evil spirits] Also, often people will nod and show they understand it when we tell them that we are not these evil creatures, but then when you walk away, you can still hear them talk about, if it is possible that we could be working with the evil spirits.

As countless anthropological studies show, removing something from the body by someone who has authority to heal (and therefor also to make ill) is intimately connected to practices of witcheraft (Meyer \& Pels, 2003; Geschiere, 1997; Evans-Pritchard, 1937). Hair-samples, but also other things that have been in contact with the body, like pieces of clothing or bodily fluids, are classic examples of objects, which can be used for both treatment and for witchcraft. When therapy sessions begin by counselors taking hair or saliva samples from the clients, this is perceived suspiciously as behavior connected to witchcraft. The counselors explained that they (the counselors) would say it was for research purposes, but that especially the removing of hair "was too strange for people". For a while the European NGO workers were also known to be "white witches" in one area where they worked with psychological counseling. As one NGO worker told me: "They called us white witches in that area for a while. They thought we did witchcraft or something like that. People were quite upset and angry for some time. There was also a very angry Facebook discussion about it, I remember. But we were there to help them, you know".

\footnotetext{
${ }^{8}$ The lute pii are believed to be a type of evil, underwater spirit, to whom one can go, if one is willing to make an immoral trade, e.g., "selling a family member to the demons in trade of riches" as one person told me. In these immoral trades, something from the person being sold is needed, e.g. a bio-sample such as hair or a piece of their clothes.
} 
These examples of different local understandings show how a new and powerful language of suffering, the diagnostic one of trauma from the Global North and the practices around "trauma", does not simply replace or erode local ideas of witchcraft and spirits. It merges with local ideas into new forms, into new ways of perceiving illness and distress. Bubandt $(2008,294)$ writes on discourses of trauma and witchcraft in Indonesia, that mental health interventions "allow trauma to become a new kind of magic for old problems". This could also be argued in northern Uganda, where trauma and spirits in unison create new understandings and ways to articulate suffering. As one informant told me: "It is difficult for people who suffer after the war, it is a problem of both spirits and trauma. But maybe the cure is that they receive medicine for the trauma, and prayers against the bad spirits".

The plasticity of the concept of "trauma" and how it merges with local idioms of distress is also echoed in many rural areas, where Pentecostal churches are abundant beyond measure. Within these small church groups, ideas of trauma and its connection to possession by demons or bad spirits is widely known and acknowledged. Here 'trauma' is the disordered state, which people may live in if God has cursed them for serious moral trespass, e.g., killing another person, or the more unfortunate situation of madness or diffuse mental illness caused by the Devil or demons for no apparent moral reason other than misfortune. In this more diffuse and less causal sense, trauma also sometimes denotes a sort of haunting which usually is connected to the violent years of war, but also can be oriented towards the uncertainties of the future (Williams \& Meinert, 2017; 2021). As one of my informants, who is a farmer in a rural area, would say: "When you can see your neighbors developing, becoming successful, and you are still stuck in poverty, using your hand-hoe in the fields, and your neighbor has a tractor - that causes trauma in you". In these versions, trauma is not necessarily a demoralized, psychologized or even intra-personal phenomenon, as much as it is a spiritualized, demonic or ethical one, pointing towards moral trespass, spiritual interference, jealousy and social insecurity.

\section{Negotiating languages of suffering in northern Uganda and beyond}

Since the 1990s, trends in humanitarian intervention have moved toward an increased focus on psychological trauma and have increasingly psychologized the effects of war on a global scale (Pedersen \& Kienzler, 2012; De Vos, 2012; Pupavac, 2004). In this way, the phenomena that humanitarian interventions focus on also increasingly overlap with and become connected to phenomena that would traditionally adhere to the spirit world and witchcraft (James, 2010; 2012; 
Mogensen \& Whyte, 2004). This is furthermore enabled by the often-similar strains of logic reigning in realms of the psychotherapeutic notions of trauma and that of witchcraft, as Bubandt $(2008,294)$ writes:

There are clear parallels between the social morality inherent in witchcraft and the morality of theories of traumatic memory that seek to represent an existing pathology as being caused by hidden (i.e., repressed or forgotten) acts of evil that took place in the past.

These entanglements call for examination and debate. However, much of the debate around the applicability of, e.g., western psychological concepts outside the imagined realm of the Global North, have hinged on premises of both a highly debated and criticized tradition/modernity distinction (mentioned early in this paper) and an epistemology of correspondence inherent in much of western philosophical and scientific though (Brinkmann \& Tanggard, 2010) ${ }^{9}$. In this final section, I will argue that these epistemological issues concerning psychological and psychiatric categories are as relevant as ever in cases where the diagnostic language of clinical psychology is being exported out to all corners of the world and meeting and merging with local spirit-concepts on its way. The starting point for this claim is, like I have shown above, that the concepts of trauma is not simply introduced in northern Uganda as a 'cosmological misfit' (Abramovich, 2010) or as a replacement of traditional cosmological elements. Instead, 'trauma' takes on a series of new meanings in different contexts. As a rough overview, trauma in northern Uganda can refer to at least the following: (1) it can be used interchangeably with PTSD in the diagnostic sense as used in current DSM-manuals; (2) it can refer to a state of disorder that the spirits have brought onto someone for moral reasons, e.g., in the case of cen; (3) as the disordered state that demons or the Devil can bring down on someone as a case of misfortune or moral trespass (mainly in Pentecostal Christian contexts); (4) sometimes as an illnessphase on a continuum ranging from mentally healthy, over disordered states of 'pre-madness', which are referred to as 'trauma', to finally a state of full-blown madness, from which people will never return and which is surpassed only by death; and finally, (5) as a more diffuse, broader concept signifying that 'something is not right' in sort of a haunted way ${ }^{10}$, but without pointing directly to the cause, e.g., when people talk of someone as a 'trauma person' or as when people say that 'competition

\footnotetext{
${ }^{9}$ There are nevertheless many exceptions to this conception e.g. Good et al. discussion of PTSD as a 'good enough' concept (2016) or Finley (2015) of how PTSD is negotiated within the American Military which are both examples of pragmatic debates on these practices.

${ }^{10}$ See Williams \& Meinert, 2021.
} 
between neighbors can cause trauma' ${ }^{11}$ thus expressing or encompassing negative emotions such as envy or frustration.

These empirical observations beckon epistemological considerations of what kind of epistemic life discourses of trauma take on in the vernacular. Since trauma has a longer array of meanings depending on contexts and actors present, I will argue that 'trauma' as it is used in social practice, cannot sufficiently be understood on basis of a correspondence theory of truth, which is what lies at the heart of the concept in its diagnostic sense (Bracken, 2002; Young, 1997; Williams $\&$ Meinert, 2017) and which many of these current debates on deployment of trauma-intervention orbit around (Broch-Due \& Bertelsen, 2016; Breslau, 2004; Pupavac, 2004). Trauma as a utilized concept within social practices in northern Uganda (and possibly elsewhere) does not (always) refer to a thing in the world, or as an active entity that lies behind events ${ }^{12}$.

Instead, it can be more constructively understood as a pragmatic concept of suffering, one that people use to transform, engage with, and cope with the world. This type of epistemology, I will argue, can more fruitfully account for the social life of the concept in post-conflict settings. The difference between these epistemologies has been debated in many corners of intellectual life, but probably most forceful by American pragmatists like John Dewey and William James (Dewey, 1922 , 1925; Menand, 1997; James, 1909), and in a European context in Wittgenstein's later philosophy (Wittgenstein, 1966, 1953). More recently, scholars debating classification and epistemology within psychology and psychiatry has taken up these currents of though. Cultural psychologist Svend Brinkmann has analyzed psychological categories such as 'grief', 'stress', 'Attention Deficit Hyperactivity Disorder' (ADHA) (2014a; 2014b; 2016a; 2016b; Brinkmann \& Kofod, 2017) as well as more general psychological phenomenon like guilt (Brinkmann, 2010) and shame (Madsen \& Brinkmann, 2012) through a pragmatist epistemology. In anthropology Susan Whyte's scholarship, and that of her colleagues and students, expresses this tradition of analysis (Whyte, 1997; Meinert \& Whyte, 2017, 2020)

The purpose here is to steer a course between essentialist and (radical) social constructionist conceptions of mental disorder, while focusing on what lives certain psychological categories enable people to live or what possibilities they serve. Brinkmann (2014) argues that this approach permits us to understand, not simply what diagnosis refer to, but what people do with their

\footnotetext{
${ }^{11}$ These different uses of trauma interestingly enough roughly mirror what Abramowitz (2009) has found in a similar study in Liberia.

${ }^{12}$ This does not mean that 'trauma' is not sometimes used in this corresponding way as in certain clinical use. The point here is that the way it is used varies depending on context and actors involved.
} 
diagnosis - how they do suffering - what possibilities become open to them and which they shut down (Brinkmann, 2014a; 2014b; Kirkegaard \& Brinkmann, 2015). The concept of 'trauma' has hardly been studied explicitly through this epistemological lens, even though the analysis of some scholars lie close to this approach, for example Abramowitz' $(2010 ; 2009)$ discussion of how local spiritidioms (such as 'open mole') become a local expression of the diagnostic 'trauma' in Liberia ${ }^{13}$. Similarly, to what Abramowitz $(2010 ; 2009)$ has shown, cen has also created a space for the deployment of psychiatric classifications systems in Acholi vocabulary and local worlds. This happens when cen and trauma are conflated simply as a translation of each other. Abramowitz calls this a 'lexical switching point', an intersection where communication and ways of understanding suffering become translatable. However, this idea of 'translation' hinges on the before mentioned correspondence theory of truth, where concepts in language have mirror images in the world and in other languages. What this understanding hides is the pragmatic and everyday-transformation that concepts and understandings undergo within social practice, that they are being transformed while translated and communicated. Therefore to understand what people do with concepts of suffering, and how they do suffering, these very concepts, I propose, must be understood, as Menand (2002, xi) proposes, as "tools - like forks and knives and microchips - that people devise to cope with the world in which they find themselves".

Examining trauma as a pragmatist concept of suffering and as a lived part of specific social practices becomes no less relevant, I argue, in cases of psychological interventions in postconflict settings. In fact, these settings add to the complexity of conceptualizing suffering because of the many different horizons of interpretation available, e.g., the realm of the local spirits, Christianity, Islam, clinical-diagnostic languages and the endless ways in which all of these can mix. Understanding 'trauma' as a pragmatic conception in social practice will better enable us to understand discourses of suffering as something connected to specific practices where certain things are done, e.g., when cleansing rituals are arranged in certain ways by NGOs to handle trauma and haunting spirits, the doing of trauma and suffering becomes part of a process of psychologizing a traditional Acholi ritual. Or when languages of suffering hinged around trauma and PTSD become the frame and justifications for taking DNA samples and conducting psychotherapy in certain ways, then the concept of trauma frames these processes of enchanting or spiritualizing the psychotherapeutic encounter. Similarly, James (2004) has shown how traumatic experience and narratives of war become assembled into 'trauma portfolios' in Haiti, were 'trauma' becomes a

\footnotetext{
${ }^{13}$ See also Behrouzan (2016) for a similar argument concerning depression in Iran.
} 
currency by which one can trade security and assistance. She writes on the 'trauma portfolio' that it “may become a symbolic index of worth or one's holdings, as well as a material representation of one's victim identity." (James, 2004, 132). Security, resources and identity are at stake in the "political economy of trauma' (James, 2004) and James asks us to consider the cost when we use such portfolios to understand human suffering in the light of pathology instead of for example as political struggles. A pragmatist conception of trauma thus entails a criticism of purely cognitivist or purely social constructivist conceptions of mental disorder. Where the cognitivist conception of trauma would hold that there are underlying etiologies of mental disorders, which simply sometimes shows up as specific cultural manifestations, the purely social constructivist conception would view the introduction of western discourses of trauma as pathologizing, as social control or expressions of biopower. Both of these current conceptions fail to grasp the agency that people in the vernacular show in doing things with the discourses of trauma, the processes of psychologization as well as spiritualization or enchantment. It is this doing of suffering and trauma, which I argue must be the focus, if we wish to understand the introduction of new languages of suffering in post-conflict societies.

\section{Possible implications of a pragmatist epistemology of trauma for psychotherapeutic interventions}

If we take this pragmatist epistemology serious when conceptualizing suffering in cross-cultural contexts, what does that mean for intervention programs focusing on trauma? According to Argenti (2016: 245), there is a risk when applying a medicalized language of suffering that these theoretical complexes become "theories of atomization.": Clients are singled out not only as suffering, but as "isolated from his or her social world, doomed to live in perpetuity in the frozen time of their original trauma" (Argenti 2016: 245). This, Argenti (2016) argues, takes places particularly when existing social structures for managing mental illness (traditional healers, churches, traditional leaders) are ignored or disregarded. A suggestion following the discussion above, could be to collaborate and enter dialogue with local actors to a higher degree on how interventions could take place and with what goals. Although, if this were done, there is a need to understand that local management of affliction is also always embedded within local power relations. A local market of healing exists, in Uganda as elsewhere, in which people sometimes compete and sometimes collaborate with one another (Williams 2019). Implementers must carefully consider who the recipients of resources are, who might be missing out, and what the consequences might be (Torre 2019). But perhaps then we could move away from understanding people as silent sufferers to, "celebrating the struggles of the 
marginalized", as Argenti (2016: 263) suggests, acknowledging the agency people still have in managing their afflictions.

\section{Conclusion}

The empire of trauma, as Fassin \& Rechtman (2009) names the expanding regime of diagnostic language from the Global North to the rest of the world, has forcefully arrived in northern Uganda within the last decade. However, from the local vantage point of rural Acholiland the local has not been subsumed under the global, but has produced new kinds of social life in its presence. Trauma discourses have become imaginaries and technologies by which people understand suffering and healing in northern Uganda, and traditional ways of handling repercussions of war, e.g., cleansing rituals against spiritual pollution, have in many cases become psychologized as well as the western diagnostic language has been vernacularized and usurped into the realm of spirits. These ideas and practices around trauma, as we have seen, do not spread globally as platonic ideas detached from social practices, but are always intimately connected to these. There is no such thing as the introduction of an idea of suffering, in this case trauma and PTSD, in abstraction from some form of social practice. This, I have argued, calls for a rethinking of the epistemology of trauma by way of pragmatist notions of suffering to properly account for how ideas of trauma become part of social life and everyday practice. The diagnostic language of suffering and trauma from the Global North has not come to rid Acholiland of its spirits, but it has changed them and given them new powers and legitimacies through association with western scientific discourse, as these different languages of suffering enter into each other's orbits.

\section{References}

Abramowitz, S. A. (2009). Psychosocial Liberia: Managing suffering in post-conflict life. Boston, USA: Harvard University Press.

Abramowitz, S. A. (2010). Trauma and humanitarian translation in Liberia: The tale of open mole. Culture, Medicine, and Psychiatry, 34(2), 353-379.

Allen, T. (2008). Ritual (Ab) use? Problems with Traditional Justice in Northern Uganda. In N. Waddell \& P. Clark (Eds.). Courting conflict? Justice, Peace and the ICC in Africa, 4754. London, UK: The Royal African Society.

Allen, Tim, and Koen Vlassenroot. (2010). The Lord's Resistance Army: myth and reality. London, UK: Zed Books. 
Allen, T., \& Schomerus, M. (2006). A hard homecoming: Lessons learned from the reception center process in Northern Uganda. Washington, DC: Management Systems International, 62(7).

Bracken, P. J. (Eds.). (1998). Rethinking the trauma of war. London, UK: Free Assn Books.

Bracken, P. (2002). Trauma: Culture, meaning and philosophy. London, UK: Whurr Publishers.

Breslau, J. (2004). Introduction: Cultures of trauma: Anthropological views of posttraumatic stress disorder in international health. Culture, Medicine and Psychiatry, 28(2), 113-126.

Brinkmann, S. (2012). Qualitative inquiry in everyday life: Working with everyday life materials. Sage.

Brinkmann, S. (2014a). Psychiatric diagnoses as semiotic mediators: The case of ADHD. Nordic Psychology, 66(2), 121-134.

Brinkmann, S. (2014b). Languages of suffering. Theory \& Psychology, 24(5), 630-648.

Brinkmann, S. (2016a). Toward a cultural psychology of mental disorder: The case of attention deficit hyperactivity disorder. Culture \& Psychology, 22(1), 80-93.

Brinkmann, S. (2016b). Diagnostic cultures: A cultural approach to the pathologization of modern life. London: Routledge.

Brinkmann, S., \& Tanggaard, L. (2010). Toward an epistemology of the hand. Studies in philosophy and education, 29(3), 243-257.

Kofod, E. H., \& Brinkmann, S. (2017). Grief as a normative phenomenon: The diffuse and ambivalent normativity of infant loss and parental grieving in contemporary Western culture. Culture \& Psychology, 23(4), 519-533.

Bubandt, N. O., Hirsch, E., Kapferer, B., Martin, E., \& Tsing, A. (2007). Anthropologists Are Talking About Anthropology After Globalisation. Ethnos, 72(1), 102-126.

Bubandt, N. (2008). Ghosts with trauma: global imaginaries and the politics of post-conflict memory. In Hedman, E. Conflict, violence, and displacement in Indonesia, 275-301. Ithaca, USA: Cornell Southeast Asia Program Publications

Bubandt, N. (2012). A psychology of ghosts: The regime of the self and the reinvention of spirits in Indonesia and beyond. In Anthropological Forum, 22(1), 1-23. 
Bubandt, N. O. (2015). Psychologising the afterlife: Ghosts and regimes of the self in Indonesia and in global media. In Steffen, V., Jöncke, S. \& Raahauge, K. (Eds.). Between magic and rationality: On the limits of reason in the modern world, 197-231. Copenhagen, Denmark: Museum Tusculanum.

Behrouzan, O. (2018). Ruptures and Their Afterlife: A Cultural Critique of Trauma. Middle EastTopics \& Arguments, 11, 131-144.

Broch-Due, V., \& Bertelsen, B. E. (Eds.). (2016). Violent reverberations: global modalities of trauma. Springer.

De Vos, J. (2012). Psychologisation in times of globalisation. Abingdon-on-Thames, UK: Routledge.

De Vos, J. (2013). Psychologization and the subject of late modernity. NYC, USA: Springer.

Dewey, J. (1925) Experience and Nature. Chicago, IL: Open Court.

Dolan, C. (2008). Social torture. The case of norther Uganda, 1986-2006. New York, USA: Berghahn Books.

Enomoto, T. (2011). Revival of tradition in the era of global therapeutic governance: the case of ICC intervention in the situation in northern Uganda. African Study Monographs, 32(3): $111-134$

Eriksen, T. H. (2010). Small Places. Large Issues. An Introduction to Cultural and Social Anthropology. London, UK: Pluto Press.

Eriksen, T. H. (2014). Globalization: The key concepts. London, UK: A\&C Black.

Evans-Pritchard, E. E. (1937). Witchcraft, oracles and magic among the Azande (Vol. 12). London, UK: Oxford.

Fassin, D. (2008). The humanitarian politics of testimony: Subjectification through trauma in the Israeli-Palestinian conflict. Cultural Anthropology, 23(3), 531-558.

Fassin, D., \& Rechtman, R. (2009). The empire of trauma: An inquiry into the condition of victimhood. Princeton, USA: Princeton University Press.

Finley, E. (2015). The Chaplain Turns to God: Negotiating Posttraumatic Stress Disorder in the American Military. In Hinton \& Hinton: Genocide and Mass Violence: Memory, Symptom, and Recovery, 263-279. Cambridge, UK: Cambridge University Press. 
Finnström, S. (2008). Living with bad surroundings: war, history, and everyday moments in northern Uganda. Durham, USA: Duke University Press.

Geschiere, P. (1997). The Modernity of Witchcraft: politics and the occult in postcolonial Africa. Charlottesville, USA: University of Virginia Press.

Harlacher, T. (2009). Traditional ways of coping with consequences of traumatic stress in Acholiland (Doctoral dissertation, Université de Fribourg).

Hinton, D. E., \& Good, B. J. (Eds.). (2016). Culture and PTSD: Trauma in global and historical perspective. Philadelphia, USA: University of Pennsylvania Press.

Hinton, D. E., \& Hinton, A. L. (Eds.). (2014). Genocide and mass violence: Memory, symptom, and recovery. Cambridge, UK: Cambridge University Press.

Hinton, D. E., \& Lewis-Fernández, R. (2011). The cross-cultural validity of posttraumatic stress disorder: implications for DSM-5. Depression and anxiety, 28(9), 783-801.

James, W. (1909). Pragmatism and four essays from the meaning of truth. World Publishing Company.

James, E. C. (2004). The political economy of 'trauma' in Haiti in the democratic era of insecurity. Culture, Medicine and Psychiatry, 28(2), 127-149.

James, E. C. (2010). Ruptures, rights, and repair: The political economy of trauma in Haiti. Social Science \& Medicine, 70(1), 106-113.

James, E. (2012). Witchcraft, bureaucraft, and the social life of(US) aid in Haiti. Cultural Anthropology, 27(1), 50-75.

Kizza, D., Hjelmeland, H., Kinyanda, E., \& Knizek, B. L. (2012). Alcohol and suicide in postconflict northern Uganda. Crisis. 33(2), 95-105.

Kirkegaard, T., \& Brinkmann, S. (2015). Rewriting stress: Toward a cultural psychology of collective stress at work. Culture \& Psychology, 21(1), 81-94.

Luhrmann, T. M. (2012). When God talks back: Understanding the American evangelical relationship with God. NYC, USA: Vintage.

Luhrmann, T. M. (2016). Building on William James: The role of learning in religious experience. In Mental Culture (pp. 155-173). Abington-on-Thames, UK: Routledge. 
Luhrmann, T.M. (2014) Knowing God, attentional learning, and the local theory of mind, Religion, Brain \& Behavior, 4:1, 78-90,

Madsen, O. J., \& Brinkmann, S. (2011). The disappearance of psychologisation. Annual Review of Critical Psychology, 8, 179-199.

Meyer, B., \& Pels, P. (2003). Magic and modernity: interfaces of revelation and concealment. Stanford, USA: Stanford University Press.

Meinert, L. \& Whyte, S. R., (2020) Legacies of Violence: The Communicability of Spirits and Trauma in Northern Uganda. In J. Seeberg, A. Roepstorff \& L. Meinert (Eds.), Beyond Biodeterminism : Anthropological Encounters with Bio-collaboratives Durham, USA: Duke University Press.

Meinert, L., \& Whyte, S. R. (2017b). “These Things Continue”: Violence as Contamination in Everyday Life After War in Northern Uganda. Ethos, 45(2), 271-286.

Menand, L. (1997). Pragmatism: A reader. NYC, USA: Vintage.

Mogensen. H, \& Whyte, S. (2004). Antropologi og medicin I dialog. Interview med Susan Reynolds Whyte. [Anthropology and medicine in dialogue. Interview with Susan Reynolds Whyte] Tidsskriftet Antropologi, 1 (1). 39-55.

Neuner, F., Pfeiffer, A., Schauer-Kaiser, E., Odenwald, M., Elbert, T., \& Ertl, V. (2012). Haunted by ghosts: Prevalence, predictors and outcomes of spirit possession experiences among former child soldiers and war-affected civilians in Northern Uganda. Social Science \& Medicine, 75(3), 548-554.

Pedersen, D. \& Kienzler, H. (2012). Strange but common bedfellows: The relationship between humanitarians and the military in developing psychosocial interventions for civilian populations affected by armed conflict. Transcultural Psychiatry, 49(3-4), 492-518.

p'Bitek, O. (1971). Religion of the Central Luo. Nairobi, Kenya: Kenya Literature Bureau.

Pupavac, V. (2004). War on the couch: the emotionology of the new international security paradigm. European journal of social theory, 7(2), 149-170.

Pupavac, V. (2006). Humanitarian politics and the rise of international disaster psychology. In Reyes, G. (ed.) Handbook of international disaster psychology, 1, 15-34. London, UK: Praeger.

Smith, R. (1997) The Norton History of the Human Sciences. New York, USA: W. W. 
Norton.

Summerfield, D. A. (1997). Legacy of war: beyond "trauma" to the social fabric. The Lancet, 349(9065), 1568.

Roberts, B., Ocaka, K. F., Browne, J., Oyok, T., \& Sondorp, E. (2008). Factors associated with posttraumatic stress disorder and depression amongst internally displaced persons in northern Uganda. BMC psychiatry, 8,1-9.

Torre, C. (2019). Psychosocial support (PSS) in war-affected countries: a literature review. Politics of Return Work-ing Paper, no.3. London School of Economics: London, UK.

Tsing, A. L. (2012). Friction: An ethnography of global connection. Princeton, USA: Princeton University Press.

Van Duijl, M., Nijenhuis, E., Komproe, I. H., Gernaat, H. B., \& De Jong, J. T. (2010). Dissociative symptoms and reported trauma among patients with spirit possession and matched healthy controls in Uganda. Culture, Medicine, and Psychiatry, 34(2), 380-400.

Victor, L., \& Porter, H. (2017). Dirty things: spiritual pollution and life after the Lord's Resistance Army. Journal of Eastern African Studies, 11(4), 590-608.

Verma, C. L. (2012). Truths out of place: homecoming, intervention, and story-making in war-torn northern Uganda. Children's geographies, 10(4), 441-455.

Whyte, S. R. (1997). Questioning Misfortune: the pragmatics of uncertainty in eastern Uganda (Vol. 4). Cambridge, UK: Cambridge University Press.

Whyte, S. R. (1999). Pragmatisme. Tidsskriftet Antropologi, (40).

Williams, L. H. (2019). In search of a stable world: Contamination of spirits and trauma in postconflict northern Uganda, PhD dissertation. School of Culture and Society, Aarhus University, Denmark.

Williams, L. H. (2019). Vernacularizing psychiatric discourse in post-conflict northern Uganda. Policy brief under the Trajectories of Displacement grant, London School of Economics: $\quad$ https://www.lse.ac.uk/africa/Assets/Documents/Policydocuments/Trajectories-of-Displacement/Policy-3-Vernacularizing-psychiatricdiscourse-in-post-conflict-northern-Uganda.pdf.

Williams, L. H., \& Meinert, L. (2017). Traumer og ånder efter krig i Uganda: Konfigurationer af vold 
og behandling. [Trauma and spirits after war in Uganda: Configurations of violence and treatment] Tidsskrift for Forskning $i$ Sygdom og Samfund, 14(26).

Williams, L. \& Meinert, L. (2020). Repetition Work: Healing Spirits and Trauma in the Churches of Northern Uganda. In M. Flaherty, L. Dalsgaard, \& L. Meinert (Eds.), Time work: Ethnographic studies of temporal agency. London, UK: Berghahn Books.

Williams, L., H. \& Meinert, L. (2021). Touched by violence: Configuring affliction after war in northern Uganda. In L. Meinert \& J. Seeberg (Eds.) Configuring Contagion in Biosocial Epidemics. New York, USA: Berghahn Press.

Wittgenstein, L. (1953). Philosophical investigations. London, Basic BlackWell.

Wittgenstein, L. (2007 [1966]). Wittgenstein: Lectures and Conversations on Aesthetics, Psychology and Religious Belief. Oakland, USA: University of California Press.

Young, A. (1997). The harmony of illusions: Inventing post-traumatic stress disorder. Princeton, USA: Princeton University Press.

\begin{abstract}
About the Author
Lars Hedegaard Williams, Ph.D. is an Anthropologist with primary research interests focusing on mental health and illness in different cultural contexts. His research has centered on how cultural notions and practices shape experiences, symptoms and course of treatment of mental illness. He has conducted long-term ethnographic fieldwork in northern Uganda and shorter ethnographic research in Denmark. He is currently a Visiting Fellow at the London School of Economics \& Political Science and an External Lecturer at University of Copenhagen at the Department of Anthropology.
\end{abstract}

